\title{
Gambaran Gangguan Muskoloskeletal pada Perawat
}

\author{
Zifriyanthi Minanda Putri ${ }^{1}$, Ilfa Khairina ${ }^{2}$, Randy Refnandes ${ }^{3}$ \\ ${ }^{1,2,3}$ Fakultas Keperawatan Universitas Andalas \\ Correspondence email: zifriyanthi@gmail.com
}

\begin{abstract}
Abstrak. Sebagian besar tenaga kesehatan merupakan tenaga keperawatan, profesi keperawatan menuntut aktifitas fisik yang tinggi menempati urutan kedua setelah pekerja industri. Gangguan muskoloskeletal sering terjadi pada petugas kesehatan, peraw at memiliki resiko lebih tinggi mengalami gangguan tersebut. Gangguan muskoloskeletal merupakan gangguan yang terjadi pada otot, tulang, tendon, pembuluh darah, sistem persyarafan, dan jaringan lunak lainnya. Tujuan dari penelitian adalah mengetahui gambaran gangguan muskoloskeletal pada perawat di RSUP. Dr. M. Djamil Padang. Metode Penelitian : Metode yang digunakan dalam penelitian ini adalah deskriptif. Jumlah sampel dalam penelitian ini sebanyak 132 orang. Pemilihan sampel dalam penelitian ini dengan metoda proporsional random sampling. Hasil penelitian didapatkan bahwa lebih dari separuh $(81,1 \%)$ perawat mengalami gangguan muskoloskeletal. Gangguan muskoloskeletal yang dikeluhkan pada bagian tubuh: bahu sebanyak 49,2\%, leher dan punggung bawah sebanyak $41,7 \%$, dan punggung atas sebanyak 32,6\%. Diharapkan perawat dapat mengidentifikasi kejadian gangguan muskoloskeletal akibat pekerjaan serta segera melaporkan pada manajemen untuk pencegahan lebih lanjut.
\end{abstract}

Kata kunci: Aktifitas fisik; Gangguan Muskuloskeletal; Perawat

Abstract. Most of the health workers are nursing staff, nursing profession demands high physical activity ranks second after industrial workers. Musculoskeletal disorders often occur in health workers, nurses have a higher risk of experiencing the disorder. Musculoskeletal disorders are disorders that occur in the muscles, bones, tendons, blood vessels, nervous system, and other soft tissues. The purpose of this study was to determine the picture of musculoskeletal disorders in nurses in General Hospital. Dr. M. Djamil Padang. Research Methods: The method used in this research is descriptive. The number of samples in this study were 132 people. The sample selection in this study was the proportional random sampling method. The results showed that more than half (81.1\%) nurses experienced musculoskeletal disorders. Musculoskeletal disorders complained of body parts: shoulders $49.2 \%$, neck and lower back $41.7 \%$, and upper back 32.6\%. It is expected that nurses can identify the incidence of musculoskeletal disorders due to work and immediately report to management for further prevention.

Keywords: Musculoskeletal Disorders; Nurses; Physical Activity

\section{PENDAHULUAN}

Sebagian besar tenaga kesehatan merupakan tenaga keperawatan dan kebidanan. Diperkirakan $50 \%$ yaitu 2,7 juta merupakan perawat dan bidan ( WHO Global Statistic Factsheet, 2017). Perawat secara global merupakan tenaga kerja terbanyak dan memiliki peran yang unik dalam mencapai tujuan kesehatan bagi seluruh masyarakat melalui pemberian layanan keperawatan (Premji dan Hatfild, 2016). Perawat mempunyai peran penting dalam sistem pelayanan kesehatan yaitu memberikan serta menyediakan layanan kesehatan primer, sekunder dam tersier (Dawson, Mclennan, Schiller, Jull, \& Hodges, 2007).

Tenaga kesehatan di Amerika Serikat sebanyak 12\% mengalami kecelakaan kerja dan sebagian besar cedera di daerah punggung dan bahu (Fujishiro, Weaver, Heaney, Hamrick, \& Marras, 2005). Prevalensi gangguan muskoloskeletal dalam 12 bulan sebesar 12\%, nyeri punggung bawah adalah gangguan muskoloskeletal yang paling umum terjadi dengan prevalensi $83 \%$, diikuti oleh nyeri pada bahu, leher, dan lutut (Smith et al , 2003 dalam S. A. Kim, Oh, Suh, \& Seo, 2014).

Gangguan muskoloskeletal merupakan gangguan yang terjadi pada otot, tulang, tendon, pembuluh darah, sistem persyarafan, dan jaringan lunak lainnya (Koutras, Buecking, Jaiger, Ruchholtz dan Heep, 2014). Gangguan muskoloskeletal sering terjadi pada petugas kesehatan (252 kasus per 10.000), perawat memiliki resiko lebih tinggi mengalami gangguan tersebut (Bureau of Labos Statistic America, 2003; Howard, 2010).

Di Indonesia sistem pelaporan dan pencatatan angka kecelakaan kerja masih memiliki keterbatasan akses berupa tidak tersedianya sumber data terkait kejadian kecelakaan kerja. Pencarian terhadap keselamatan kerja pada beberapa sumber pangkalan data nasional tidak mencantumkan kejadian kecelakaan kerja terutama terkait gangguan muscoloskeletal pada petugas kesehatan. Hal ini dapat disimpulkan bahwa kejadian pada petugas kesehatan terutama pada perawat belum menjadi perhatian khusus di tingkat nasional dan lokal.

Hasil beberapa penelitian di Indonesia ditemukan pada tahun 2010 di RSUD yang berada di Kota Jakarta, keluhan subjektif Low Back Pain terjadi pada 83,3\% pada petugas kesehatan (Simanjuntak, 2017). Sedangkan pada penelitian di RSUD Purbalingga didapatkan sebanyak $18,75 \%$ perawat mengalami low back pain akibat pekerjaannya (Fathoni, Handoyo, Swasti, 2019).

Berdasarkan studi pendahuluan yang dilakukan oleh peneliti melalui wawancara terhadap perawat, 
peneliti menemukan laporan verbal dari 2 kepala ruangan menyatakan ada beberapa perawat mengeluhkan nyeri punggung, bahu, dan nyeri pinggang. Perawat mengeluhkan kekurangan tenaga di ruangan sehingga beban kerja meningkat.

Tujuan dari penelitian ini adalah untuk mendapatkan gambaran gangguan muskoloskeletal pada perawat di RSUP Dr. M.Djamil.

\section{METODE}

Penelitian ini merupakan penelitian kuantitatif dengan menggunakan desain deskriptif. Populasi dalam penelitian ini adalah seluruh perawat pelaksana di Instalasi Rawat Inap Bedah \& Non Bedah RSUP Dr. M.Djamil Padang,yang berjumlah 160 orang. Pemilihan sampel dalam penelitian ini secara random dengan metoda proporsional random sampling. Sampel dalam penelitian ini adalah seluruh perawat pelaksana yang bekerja di Instalasi Rawat Inap Bedah \& Non Bedah RSUP Dr. M.Djamil Padang. Untuk mengantisipasi kemungkinan sampel yang drop out, dilakukan penambahan $15 \%$ dari jumlah sampel, sehingga jumlah sampel penelitian sebanyak 132 orang.

Waktu penelitian dilaksanakan selama 9 bulan dari bulan Maret 2018 - November 2018. Penelitian ini telah lolos kaji etik dari Komite Etik Penelitian Kesehatan RSUP Dr. M.Djamil dengan nomor: PE.218.2018.

\section{HASIL DAN PEMBAHASAN} berikut :

Hasil penelitian dapat digambarkan dalam tabel

Tabel 1. Distribusi Frekuensi Gangguan Muskoloskeletal Pada Perawat di RSUP Dr. M. Djamil Padang

\begin{tabular}{lcc}
\hline Gangguan Muskoloskeletal & f & \% \\
\hline Tidak & 25 & 18,9 \\
Ya & 107 & 81,1 \\
Total & $\mathbf{1 3 2}$ & $\mathbf{1 0 0}$ \\
\hline
\end{tabular}

Berdasarkan di atas diketahui distribusi frekuensi gangguan muskoloskeletal pada perawat, dimana lebih dari separuh $(81,1 \%)$ perawat mengalami gangguan muskoloskeletal.

Tabel 2. Distribusi Frekuensi Bagian Tubuh Yang Mengalami Rasa Sakit, Tidak Nyaman dan Nyeri (Gangguan Muskoloskeletal) Pada Perawat di RSUP Dr. M. Djamil Padang

\begin{tabular}{lcccc}
\hline Gangguan Muskoloskeletal & \multicolumn{2}{c}{ Ya } & \multicolumn{2}{c}{ Tidak } \\
Bagian Tubuh & f & \% & f & \% \\
\hline Leher & 55 & 41,7 & 77 & 58,3 \\
Bahu & 65 & 49,2 & 67 & 50,8 \\
Punggung Atas & 43 & 32,6 & 89 & 67,4 \\
Siku & 11 & 8,3 & 121 & 91,7 \\
Punggung Bawah & 55 & 41,7 & 77 & 58,3 \\
Pergelangan Tangan & 22 & 16,7 & 110 & 83,3 \\
Bokong Paha & 35 & 26,5 & 97 & 73,5 \\
Lutut & 40 & 30,3 & 92 & 69,7 \\
Pergelangan Kaki & 30 & 22,7 & 102 & 77,3 \\
\hline
\end{tabular}

Berdasarkan tabel di atas diketahui distribusi frekuensi bagian tubuh yang mengalami rasa sakit, tidak nyaman, nyeri pada perawat: bahu sebanyak $49,2 \%$, leher dan punggung bawah sebanyak $41,7 \%$ dan punggung atas sebanyak $32,6 \%$.

\section{Pembahasan}

Hasil penelitian menunjukkan lebih dari separuh $(81,1 \%)$ perawat mengalami gangguan muskoloskeletal. Gangguan muskoloskeletal yang dikeluhkan responden pada bagian tubuh seperti: bahu sebanyak $49,2 \%$, leher dan punggung bawah sebanyak $41,7 \%$ dan punggung atas sebanyak $32,6 \%$.

Gangguan muskoloskeletal merupakan gangguan yang terjadi pada otot, tulang, tendon, pembuluh darah, sistem persyarafan, dan jaringan lunak lainnya (Koutras, Buecking, Jaiger, Ruchholtz dan Heep, 2014).

Tenaga kesehatan di Amerika Serikat sebanyak 12\% mengalami kecelakaan kerja dan sebagian besar cedera di daerah punggung dan bahu (Fujishiro, Weaver, Heaney, Hamrick, \& Marras, 2005). Prevalensi gangguan muscoloskeletal dalam 12 bulan sebesar $12 \%$, nyeri punggung bawah adalah gangguan muscoloskeletal yang paling umum terjadi dengan prevalensi 83\%, diikuti oleh nyeri pada bahu, leher, dan lutut (Smith et al , 2003 dalam S. A. Kim, Oh, Suh, \& Seo, 2014).

Foley (2004) menyatakan tenaga perawat berisiko lebih tinggi mengalami kecelakaan kerja dari pada pekerja kesehatan lainnya. Perawat memiliki risiko nyeri punggung enam kali lebih tinggi dibandingkan profesi lain (Cohen, Culpepper \& Carter, 1996 dalam Dawson et al, 2007).

Perawat yang mengalami gangguan muskoloskletal akan mengeluhkan ketidaknyamanan rasa nyeri, dan keterbatasan pergerakan sehingga memberikan batasan terhadap pemenuhan kebutuhan sehari-hari (Hindawi, 2017). Hasil analisa kuesioner ditemukan sebanyak 7,6\% responden yang mengalami gangguan muskoloskeletal pada bagian punggung atas dan lutut merasa terhalang dalam melakukan aktivitas sehari-hari. Rentang skala nyeri yang dirasakan di daerah punggung bawah sebanyak $3,8 \%$ pada skala nyeri 5 .

Gangguan muskoloskletal mengakibatkan rasa nyeri, sakit kronis, stres psikologis, dan keterbatasan pergerakan sehingga memberikan batasan terhadap pemenuhan kebutuhan sehari-hari. Tidak terpenuhinya kebutuhan dasar sehari-hari memunculkan keluhan fisik yang menurunkan kualitas hidup penderita (S. E. Kim, 2013; Yan, 2017).

Cedera dan nyeri punggung memiliki dampak besar pada efisiensi kerja tenaga keperawatan. Perawat menempati posisi ketujuh tertinggi dari semua pekerjaan yang mengambil hari libur kerja akibat nyeri punggung (Bureau of Labor Statistic, 2002 dalam Dawson et al, 2007). Hal lainnya adalah penundaan pekerjaan akibat sifat kronis dari penyakit tersebut (S. E. Kim, 2013). 
Akibat luka-luka tersebut 600.000 pekerja kehilangan pekerjaannya setiap tahunnya, (Malone, 2000; Maul, Läubli, Klipstein, \& Krueger, 2003, dalam Sharafkhani et al., 2014). Menurut Gropelli \& Corle, 2010 dalam (Buckheit \& Ostendorf, 2013) 12\% perawat meninggalkan profesinya setiap tahun karena nyeri punggung akibat kerja.

Gangguan muskoloskeletal merupakan hal yang merugikan jika terjadi pada petugas kesehatan. Hal ini memberikan dampak baik secara biologis, psikologis,sosial, dan organisasi.

\section{SIMPULAN}

Gambaran gangguan muskoloskeletal pada perawat, dimana sebagian besar $(81,1 \%)$ perawat mengalami gangguan muskoloskeletal. Gangguan muskoloskeletal yang dikeluhkan responden hamper separo pada bagian tubuh seperti: bahu, leher dan punggung bawah, dan punggung atas.

\section{DAFTAR PUSTAKA}

Buckheit, K., \& Ostendorf, J. (2013). Ergonomics and Nursing in Hospital Environments, 61(10), 429440. https://doi.org/10.3928/21650799-20130916$\underline{09}$

Bridger RS. 2008. Intrduction to Ergonomics. Edisi 3. London: CRC Press

Carayon, P. (2012). Human Factors and Ergonomic in Health Care and Patient Safety. Second Edition. Boca Raton, FL: CRC Press.

Cho K, Cho HY, Han GS. 2016. Risk factors associated with musculoskeletal symptoms in Korean dental practitioners. J Phys Ther Sci, 28(1): 56-62.

Cipriano, Pamela F. (2016). Safe nurses, safe patients. American Nurse; Washington Vol. 48, Iss. 6,

Dawson, A. P., Mclennan, S. N., Schiller, S. D., Jull, G. A., \& Hodges, P. W. (2007). systematic review, 642-650.

https://doi.org/10.1136/oem.2006.030643

Dyck, Dianne E G. (2015). Are We Making ADifference? Work Absence Changes. Journal : The Official Publication of the Ontario Occupational Health Nurses Association; Toronto Vol. 34, Iss. 1.

Fujishiro, K., Weaver, Ã. J. L., Heaney, C. A., Hamrick, C. A., \& Marras, W. S. (2005). The Effect of Ergonomic Interventions in Healthcare Facilities on Musculoskeletal Disorders, 347, 338-347. https://doi.org/10.1002/ajim.20225.

Ilyas, Y. 2004. Perencanaan SDM Rumah Sakit : Teori, Metoda, dan Formula. Depok. FKM-UI.

Kim, S. A., Oh, H. S., Suh, Y. O., \& Seo, W. S. (2014). An integrative model of workplace self-protective behavior for Korean nurses. Asian Nursing Research, 8(2), 91-98. https://doi.org/10.1016/j.anr.2014.05.003

Kim, S. E. (2013). Ergonomic Interventions as a
Treatment and Preventative Tool for WorkRelated Musculoskeletal Disorders, 6(3), 339348.

Mao, X., Jia, P., Zhang, L., Zhao, P., \& Chen, Y. (2015). An Evaluation of the Effects of Human Factors and Ergonomics on Health Care and Patient Safety Practices: A Systematic Review, 1-20. https://doi.org/10.1371/journal.pone.0129948

Maria, N., Alexandre, C., Antonio, M., Moraes, A. De, Corrêa, H. R., Angélica, S., \& Saúde, C. De. (2001). Evaluation of a program to reduce back pain in nursing personnel * Avaliação de programa para reduzir dores nas costas em trabalhadores de enfermagem, 35(4), 356-361.

Ricci, F., Chiesi, A., \& Bisio, C. (2016). Effectiveness of occupational health and safety training A systematic review with meta-analysis, 28(6), 355377. https://doi.org/10.1108/JWL-11-2015-0087

Sharafkhani, N., Khorsandi, M., \& Shamsi, M. (2014). Low Back Pain Preventive Behaviors Among Nurses Based on the Health Belief Model Constructs. 